\title{
PENDAPATAN NON HALAL SEBAGAI SUMBER DAN PENGGUNAAN QARDHUL HASAN DALAM PERSPEKTIF ISLAM
}

\author{
Harkaneri $^{1}$ \& Hana Reflisa ${ }^{2 *}$ \\ 1\&2 Fakultas Ekonomi dan Ilmu Sosial, Universitas Islam Negeri Sultan Syarif Kasim Riau \\ Jl. HR. Soebrantas Panam KM. 15 No. 155 Tampan Pekanbaru, 28293 \\ e-mail : $\underline{\text { harkaneri@gmail.com }}$
}

\begin{abstract}
Abstrak : Penelitian ini bertujuan untuk mengetahui dan memahami tinjauan Islam mengenai pendapatan non halal sebagai sumber dan penggunaan dana qardhul hasan pada perbankan syariah. Penelitian ini menggunakan metode kualitatif dengan pendekatan fenomenologi dimana data diperoleh dengan melakukan wawancara mendalam dengan informan yang dipilih berdasarkan teknik purposive sampling. Pemilihan informan untuk penelitian fenomenologi ini dikategorikan dari ulama, praktisi perbankan syariah dan akademisi.

Hasil penelitian ini mengungkapkan bahwa adanya unsur riba pada bunga yang merupakan sumber pendapatan non halal. Penggunaan pendapatan non halal dalam dana qardhul hasan selayaknya tidak disalurkan dalam bentuk pinjaman bergulir (qardhul hasan) sebab adanya hukum haram yang melekat pada bunga. Sehingga penggunaanya secara khusus disalurkan pada kepentingan umum yang bersifat non komsumtif yang berfungsi untuk membersihkan dana haram pada perbankan syariah.
\end{abstract}

Kata Kunci : Pendapatan Non Halal, Qardhul Hasan, Fenomenologi, Perspektif Islam

SYARIKAT : Jurnal Rumpun Ekonomi Syariah Volume 1, Nomor 2, Desember 2018 


\section{PEDAHULUAN}

Industri perbankan syariah nasional terus tumbuh berkembang selama lebih dari dua dekade pengembangan sejak tahun 1992.Perbankan syariah adalah bank yang tidak hanya bertujuan pada profit (profit oriented)semata melainkan juga pada kepentingan sosial. Produk perbankan syariah yang sesuai dengan prinsipta'awun (tolong menolong)salah satunya yaituqardhul hasan. Dalam literatur fikih klasik, konsepqardhul hasan dikategorikan dalam akad tolong menolong danbukan transaksi komersial(Purwadi, 2011). Penelitian yang dilakukan Badaruddin
(2011) berpendapat bahwa kontribusi pembiayaan qardhul hasan bagi nasabah memiliki mashlahat yang sangat besar.

Berdasarkan penelitian Purwadi (2011) bahwa peran yang begitu besar dari produk pembiayaan qardhul hasan menarik peneliti untuk meneliti lebih lanjut mengenai sumber dana qardhul hasan yang bersumber dari pendapatan non halal yang akan di tinjau dalam perspektif Islam. Dalam hal ini pendapatan non halal bergerak secara fluktuatif namun cenderung meningkat seperti table 1 berikut ini :

Tabel 1. Pendapatan Non Halal

\begin{tabular}{|c|l|c|c|c|}
\hline NO & \multicolumn{1}{|c|}{ BANK SYARIAH } & $\mathbf{2 0 1 2}$ & $\mathbf{2 0 1 3}$ & $\mathbf{2 0 1 4}$ \\
\hline 1 & Bank Muamalat & - & 1048 & 1637 \\
\hline 2 & Bank Syariah Mandiri & 454 & 191 & 442 \\
\hline 3 & BNI Syariah & 254 & 121 & 1 \\
\hline 4 & BRI Syariah & 47 & 337 & 161 \\
\hline 5 & Bank Syariah Bukopin & 75 & 58 & 130 \\
\hline 6 & BCA Syariah & 1 & 1 & 1 \\
\hline 7 & BJB Syariah & 4 & 98 & 220 \\
\hline 8 & Bank Mega Syariah & 53 & 128 & 166 \\
\hline 9 & Bank Maybank Syariah Indonesia & 11 & 28 & 27 \\
\hline
\end{tabular}

Sumber: Otoritas Jasa Keuangan (OJK). Diolah Peneliti

Perbedaan penelitian saat ini dengan penelitian sebelumnya adalah penelitian yang dilakukan saat ini menggunakan metode kualitatif dengan pendekatan fenomenologi. Peneliti akan melihat perspektif syariah mengenai pendapatan non halal sebagai sumber dan penggunaan dana qardhul hasan menurut ulama ahli, akademisi yang ahli bidang akuntansi syariah dan ekonomi syariah serta praktisi perbankan syariah. Sehingga, penelitian ini akan memberikan informasi yang lebih mendalam mengenai status pendapatan non halal pada sumber dan penggunaan qardhul hasan. 


\section{TINJAUAN PUSTAKA}

Qardhul hasan berasal dari kata qard, menurut Ali dan Muhdlar (1996) dalam Burhanudin (2012) bahwa secara etimologi kata qard berasal dari qa-ra-da yang berarti memotong.Pengeritan qardh menurut Dewan Syariah Nasional sebagimana tercantum dalam fatwa Dewan Syariah nomor 19/DSN-MUI/IX/2001 tentang alqardh menyebutkan bahwa al-qardh adalah suatu akad pinjaman kepada nasabah tertentu dengan ketentuan bahwa nasabah wajib mengembalikan dana yang diterimanya kepada lembaga keuangan syariah (LKS) pada waktu yang telah disepakati oleh LKS dan nasabah. Ada suatu jenis qardh yang disebut qardh ul-hassan atau qardh hassan, yaitu perjanjian qardh yang khusus untuk tujuan sosial(Khir, Giupta dan Shanmugam, 2008; 186 dalam Sjahdeini, 2014:342).

Dalil yang menguatkan keputusan ulama memperbolehkan transaksi qardh yang dijelaskan Antonio (2013:131) bahwa transaksi qardh dibolehkan oleh para ulama berdasarkan hadist riwayat Ibnu Majjah dan ijma ulama.

1. Alquran

"Siapakah yang mau meminjamkan kepada Allah pinjaman yangbaik, maka Allah akan melipat-gandakan (balasan) pinjaman ituuntuknya dan dia akan memperoleh pahala yang banyak." (Qs.al-Hadid:11)

Makna dari firman Allah SWT ini menjelaskan bahwa sebagai hamba Allah SWT, Allah menyeru untuk membelanjakan harta di jalan-Nya. Sehingga manusia harus meyakini bahwa memberikan pinjaman kepada sesama manusia karena Allah maka sama maknanya dengan membelanjakan harta di jalan-Nya. Karena rezeki setiap manusia adalah sebuah titipan dari Allah SWT dan sebagiannya merupakan hak orang lain yang wajib diberikan dengan cara yang baik. Dalam firman Allah yang lain, surah al-Baqarah ayat 245 juga menjelaskan makna yang sama dengan surah di atas.

2. Hadis

Antonio (2013: 132) menjelaskan hadis yang berkaitan dengan qardh, yaitu sebagai berikut :

Ibnu Mas'ud meriwayatkan bahwa Nabi saw, Berkata,"bukan seorang muslim (mereka) yang meminjamkan muslim (lainnya) dua kali kecuali yang satunya adalah (senilai) sedekah."(HR Ibnu Majah no. 2421, Kitab al-Ahkam; ibnu Hibban dan Baihaqi)

Anas bin Malik berkata bahwa Rasulullah berkata, "Aku melihat pada waktu malam di-isra'-kan, pada pintu surga tertulis : sedekah dibalas sepuluh kali lipat dan qardh delapan belas kali. Aku bertanya : 'Wahai Jibril, mengapa qardh lebih utama dari sedekah? Ia menjawab, "karena peminta-minta sesuatu dan ia punya, sedangkan yang meminjam tidak akan meminjam kecuali karena keperluan."(HR Ibnu Majah no. 2422, kitab al-ahkam dan Baihaqi)

Dari hadis tersebut menjelaskan bahwasannya sangat utamanya saling tolong menolong diantara sesama. Begitu pula pada akad qardhul hasanyang merupakan akad pinjaman yang dapat membantu orang lain dari kesusahan, karena dengan pinjaman tersebut orang lain akan merasa lebih ringan untuk menghadapi masalah 
keuangannya dan niscaya pemberi pinjaman akan mendapatkan balasannya yaitu janji Allah yang akan memberi kemudahan bahkan secara tegas alan melepaskan kesusahannya dihari kiamat kelak (Solehudin, Auliyah dan Zuhdi, 2014).

3. Ijma

Menurut Antonio (2013: 132-133) bahkan para ulama telah menyepakati al-qardh boleh dilakukan. Hal ini dijelaskan bahwa fatwa ini didasari dari manusia sebagai makhluk sosial yang membutuhkan pihak lain untuk mempertahankan hidup. Tidak ada seorangpun yang memiliki segala barang yang ia butuhkan. Oleh karena itu pinjam meminjam sudah menjadi satu bagian dari kehidupan di dunia ini.

Sumber dana qardhul hasan disebutkan dalam Explosure DraftPernyataan Standar Akuntansi Keuangan 101 (2014): Penyajian Laporan Keuangan Syariah khususnya mengenai laporan sumber dan penggunaan dana kebajikan pada paragraf ke-123a. Dalam hal ini sumber qardhul hasan berasal dari penerimaan infak, sedekah, hasil pengelolaan wakaf sesuai dengan perundang-undangan yang berlaku, pengembaliandana kebajikan produktif, denda dan penerimaan dana non halal. Pelaporan qardhul hasan disajikan tersendiri dalam laporan sumber dan penggunaan dana karena aset tersebut bukan aset bank yang bersangkutan.

Menurut Nurhayati dan Wasilah (2015:263) bahwa sumber dana qardhul hasan dari eksternal dan internal. Sumber eksternal berasal dari dana qardh yang diterima oleh bank syariah dari pihak lain (misalnya dari sumbangan, infak, sedekah dan sebagainya). Sedangkan contoh sumber dana qardh yang disediakan para pemilik entitas bisnis, hasil pendapatan non halal dan denda lain-lainnya. Sedangkan menurut Antonio (2013: 133) qardhul hasan bersumber dari dana umat seperti zakat, infak dan sedekah. Disamping itu terdapat sumber dana lain seperti jasa nostro di bank koresponden yang konvensional, bunga atas jaminan $\mathrm{L} / \mathrm{C} \mathrm{di}$ bank asing.

Pendapatan non halal adalah penerimaan atau uang masuk pada bank syariah yang berasal dari transaksi non halal. Salah satu contohnya adalah pendapatan bunga.

Pendapatan non halal salah satunya bersumber dari bunga bank. Terdapat pendapat ulama yang menyatakan bahwa bunga bank itu riba, maka haram. Dengan demikian pendapatan non halal yang berasal dari bunga bank merupakan riba, hal demikian jelas dilarang dalam nash AlQur'an dan Hadist. Menurut Antonio (2013:48-54) bahwa terdapat firman Allah yang menjelaskan mengenai riba seperti salam surat Ar-Ruum ayat 3, an-Nisa ayat 160-161, Ali-Imran ayat 130 dan alBaqarah ayat ayat 278-279.

Pada prinsipnya perbankan syariah dilarang memperoleh penerimaan non halal. Penerimaan non halal pada umumnya terjadi dalam kondisi yang tidak dapat dihindari. Dalam ED PSAK 101 (revisi 2014): Penyajian LaporanKeuangan Syariah, khususnya mengenai laporan sumber dan penggunaandana kebajikan pada paragraf 126 menjelaskan bahwa pendapatan nonhalal adalah semua penerimaan dari kegiatan yang tidak sesuai dengan prinsip syariah antara lain 
penerimaan jasa giro atau bunga yang berasal dari bank konvensional.

\section{METODE}

Penelitian ini menggunakan metode kualitatif dengan pendekatan fenomenologi. Menurut Martono (2015:206) penelitian fenomenologi (phenomenology research) adalah tipe penelitian yang menggambarkan pemaknaan beberapa individu mengenai pengalaman hidupnya, pemaknaan mereka mengenai konsep atau fenomena tertentu.

Jenis dan sumber data yang digunakan dalam penelitian ini adalah data primer dan data sekunder. Data primer adalah sekumpulan informasi yang diperoleh peneliti langsung dari lokasi penelitian melalui sumber pertama (seperti informan melalui wawancara) atau melalui hasil pengamatan yang dilakukan sendiri oleh peneliti (Martono,2015:65). Untuk menjawab riset question atas penelitian yang dilakukan maka peneliti memperoleh data dengan wawancara kepada informan. Data Sekunder dalam penelitian ini misalnya laporan keuangan perbankan syariah terutama laporan sumber dan penggunaan dana kebajikan di perbankan syariah.

Objek penelitian dalam penelitian ini adalah perbankan syariah di Indonesia. Kemudian dalam penelitian ini, perbankan syaariah dipilih berdasarkan kriteria sebagai berikut : (1) merupakan Bank Umum Syariah; (2) BUS harus mengungkapkan Laporan Sumber dan Penggunaan Dana Kebajikan dalam 3 tahun teraqkhir dari 2012-2014; (3) dan BUS harus Memiliki pendapatan non halal pada salah satu sumber dana kebajikan dalam jangka waktu 3 tahun terakhir. Sehingga berdasarkan kriteria di atas, ada 9 BUS yang dijadikan objek penelitian, yaitu PT. Bank Muamalat, PT. Bank Syariah Mandiri, PT. BNI Syariah, PT. BRI Syariah, PT. Bank Syariah Bukopin, PT. Bank Jabar Banten Syariah, PT. Bank BCA Syariah, PT. Bank Mega Syariah dan PT. Bank Maybank Syariah Indonesia.

Teknik pengumpulan data yang digunakan dalam dalam penelitian ini yaitu, wawancara, dokumentasi dan studi kepustakaan. Semua metode tersebut digunakan dalam penelitian guna memperoleh data yang relevan dan berkualitas.

Informan merupakan orang yang memberikan penjelasan atau informasi secara rinci dalam proses penelitian(Martono, 2015: 120). Dalam penelitian ini, pemilihan informan menggunakan teknik purposive sampling. Peneliti sengaja memilih informan yang telah dibagi dan disesuaikan berdasarkan bidang dan keahliannya, yaitu sebagai berikut :

a. Praktisi perbankan syariah yang dipilih adalah pimpinan salah satu cabang utama di salah satu daerah di Indonesia.

b. Ulama, informan yang mempunyai pekerjaan atau keahlian sebagai ulama yang memahami tafsir, hadist dan fiqh.

c. Akademisi, kriteria informan akademisi yaitu yang memiliki gelar atau keahlian dalam bidang muamalat syariah dan akuntansi syariah.

Menurut Sugiyono (2013:369) menyatakan bahwa triangulasi diartikan sebagai pengecekan data dari berbagai sumber dengan berbagai cara dan berbagai waktu, berikut penjelasannya. 
a. Triangulasi sumber yaitu pemeriksaan keabsahan data yang dapat dilakukan dengan cara mengecek data yang telah diperoleh melalui beberapa sumber (Sugiyono, 2013: 370).

b. Triangulasi teknik pengumpulan dataialah untuk menguji kredibiltas data yang dilakukan dengan cara mengecek data kepada sumbersumber yang sama dengan teknik yang berbeda (Sugiyono, 2013:353).

c. Triangulasi waktu yaitu untuk menguji kredibilitas data yang dilakukan dengan cara melakukan pengecekan dengan wawancara atau teknik lain dalam waktu atau situasi yang berbeda (Sugiyono, 2013: 371).

Teknik analisis data untuk penelitian fenomenologi pada penelitian ini mengacu pada yang disampaikan Amadeo Giori (Raco \& Tanod, 2011: 119-123 dalam Nuradilla, Rusmana dan Warsidi, 2014), yaitu:

a) Peneliti membaca keseluruhan ungkapan yang disampaikan oleh informan dengan tujuan untuk mendapatkan arti umum dari informasi tersebut, ketika membaca keseluruhan ungkapan yang disampaikan oleh informan, peneliti juga berpegang pada konteks penelitian yang dilakukan agar peneliti dapat menangkap ungkapan yang dimaksud oleh informan.

b) Peneliti akan membaca keseluruhan teks kembali dengan tujuan khusus, yaitu untuk memilih atau membedakan (discriminating) unit makna (meaning unit) dan dengan perhatian penuh pada fenomena yang sedang diteliti oleh peneliti.

c) Peneliti melihat dan membaca seluruh unit makna sambil memperhatikan apakah unit makna tersebut benar-benar memiliki keterkaitan dengan topik yang dibahas dan diteliti oleh peneliti.

d) Peneliti membuat sintesa dari semua unit makna yang ditranformasi dalam satu statement yang sesuai dengan pengalaman informan.

\section{HASIL}

\section{Realitas Penggunaan Pendapatan Non Halal dalam Sumber Dana Qardhul Hasan}

Adanya pendapatan non halal pada perbankan syariah disebabkan adanya transaksi antara perbankan syariah dengan perbankan konvensional yang menimbulkan bunga bank. Menurut Solehudin, Auliyah dan Zuhdi (2014) bahwa perbankan syariah masih membutuhkan kerja sama dengan perbankan konvensional sebab posisi perbankan syariah di Indonesia yang kurang tepat.

Konsisten dengan yang disampaikan Bapak Imdibkri selaku Pimpinan Cabang di salah satu perbankan syariah bahwa dalam kondisi tertentu bank syariah menepatkan dana pada bank konvensional. Hal ini menimbulkan bunga yang diterima bank syariah, sehingga bunga inilah yang dikategorikam sebagai pendapatan non halal. Informan juga menyampaikan pendapatan non halal yang diterima diperbankan yang dipimpinannya hanya berasal dari bunga bank.

“...sumbernya itu tadi. Cuma satu yang kita terima sekarang. Itu dari bunga, 
dana kita yang kita pakai di konvensional, satu atau dua hari. Di kasih bunga. Itu kita kategorikan non halal."
Pendapatan non halal dalam laporan sumber dan penggunaan dana kebajikan pada perbankan syariah cenderung meningkat. Hal ini dapat dilihat pada diagram tiga tahun terakhir di bawah ini.

\section{Gambar 1. Pendapatan Non Halal dalam Laporan Sumber dan Penggunaan Dana Kebajikan pada Perbankan Syariah Selama 3 Tahun}

\begin{tabular}{|r|r|r|r|}
\hline & \multicolumn{3}{|l|}{} \\
\hline
\end{tabular}

Sumber: Otoritas Jasa Keuangan (OJK). Diolah Peneliti

Dari gambar di atas menunjukkan pendapatan non halal pada perbankan syariah bergerak fluktuatif tiap tahunnya namun cenderung meningkat. Hal ini memungkinkan munculnya pendapatan non halal di perbankan syariah kian meningkat tiap tahunnya.
Pandangan Ulama, Akademisi dan Praktisi: Pendapatan Non Halal sebagai Sumber dan Penggunaan Dana Qardhul Hasan dalam Perspektif Islam

Pemanfaatan pendapatan non halal: ahsan digunakan sebagai sumber dana qardhul hasan Mengembalikan dana umat kepada umat

SYARIKAT : Jurnal Rumpun Ekonomi Syariah Volume 1, Nomor 2, Desember 2018 
Dalam hal ini peneliti akan memaparkan sudut pandang dari ahli ulama. Adalah Ustaz H. Abdul Shomad, LC., D.E.S.A, informan berprofesi sebagi ulama serta dosen di salah satu Universitas Negeri di Indonesia.Menurutkeputusan Majma' al Fiqh al-Islamy, fatwa Mufti al-Azhar (Syekh Abdulathif Hamzah), mufti ulama besar Saudi Arabia, Syekh Hisam 'Afanah, dikutip oleh Ustaz H. Abdul Shomad, LC., D.E.S.A, maka informan berpendapat bahwa penggunaan pendapatan non halal boleh digunakan namun tidak tergolong sebagai sedekah.

Dari keputusan fatwa ulama-ulama tersebut mengungkapkan bahwa semua harta yang berasal dari bunga bank maka haram menurut syariat Islam, baik bagi penerima bunga maupun bagi pihak lain seperti keluarga namun ada pengecualian dari pernyataan tersebut. Bahwa bunga bank boleh dimanfaatkan tetapi untuk fakir miskin, dan kepentingan umum. Sebagaimana yang dinyatakan Antonio (2013: 133) pemanfaatan bunga ini didasarkan pada kaidah akhaffu dhararain (mengambil mudharat yang lebih kecil) bila dibandingkan dengan dana tersebut digunakan oleh perbankan konvensional dalam bisnis utamanya yang hanya berprosentase pada bunga dan akhirnya bunga akan menimbulkan bunga lainnya.

Ustaz H. Abdul Shomad, LC., D.E.S.A menyatakan hal yang serupa pada hasil wawancara yang telah dilakukan. Berdasarkan asumsi informan bahwa penggunaan pendapatan non halal layak digunakan untuk kepentingan umum dan fakir miskin. Berikut pernyataannya.

“..... lalu diserahkan kepada fakir miskin bukan sebagai sedekah. Karena Allah tidak menerima yang kotor. Allah Maha Suci, Allah menerima kecuali yang suci. Lalu saat itu apa fungsiuang itu? Mengembalikan uang umat kepada umat. Umat ini dianggap umat yang satu. Awalnya uang ini milik si ' $A$ ', ' $B$ ', 'C' dan lainlain. Lalu diberikan kepada ' $F$ ', ' $G$ ', ' $H$ ', ' $I$ ', 'J', 'K'. Diberikan uang si 'Ini' kepada si 'Ini'. Ini masih diangggap satu umat. Yang tak boleh itu, uang hasil bunga itu saya makan untuk saya. Maka hendaklah ia menyerahkan kepada orang banyak dan untuk kepentingan umum. Yang dinikmatin orang banyak. Bukan dinikmati person (perorang). Karena tak boleh dia makan,haram! Jadi fungsi uang saat itu bukan sebagai sedekah, mengembalikan uang umat kepadaumat. Karena itu milik bersama. Disitu letak persimpangannya, mirip tampaknya. Loh dimakan tak boleh, disedekahkan kok boleh?Bukan sedekah. Makanya disitu tidak boleh dengan niat sedekah.Gak boleh dengan niat sedekah. Karena tak boleh sedekah, lalu kalo dibuang? Dibuang haram. Maka dipakai untuk kepentingan umum,untuk orang banyak. Fakir miskin, anak yatim, membangun amah- murafik, membangun sekolah, MDA, musytafaya (rumah sakit).Tidak dianggap sebagai sedekah. Mensucikan diri dari yang haram, dikembalikan kepada umat."

Berdasarkan yang dinyatakan Ustaz H. Abdul Shomad, LC., D.E.S.A dapat diambil suatu kesimpulan bahwa beliau sependapat dengan fatwa ulama-ulama yang setuju (pro) pada penggunaan pendapatan nonhalal sebagai sumber dana qardhul hasan. Menurut informan secara implisit menyatakan bahwa pendapatan non halal 
tidak diakui sebagai pendapatan oleh bank syariah bahkan untuk disedekahkan. Selanjutnya,dengan adanya penepatan dana pada perbankan konvensional menimbulkan bunga yang tidak dapat dihindari. Dalam hal ini bunga (interest) tidak diakui sebagai pendapatan pada perbankan syariah, melainkan dimanfaatkan untuk umat seperti masyarakat umum (ekonomi lemah). Maka disebut tadi mengembalikan dana umat kepada umat. Sebab sumber awalnya berasal dari umat dan dikembalikan kepada umat. Informan menyatakan bahwa umat disini maknanya umat yang satu. Untuk melihat alur distribusi pendapatan non halal dalam makna mengembalikan dana umat kepada umat dapat di lihat pada gambar 2 berikut ini :

\section{Gambar. 4.2 Alur Distribusi Pendapatan Non Halal dalam Makna Mengembalikan Dana Umat Kepada Umat}

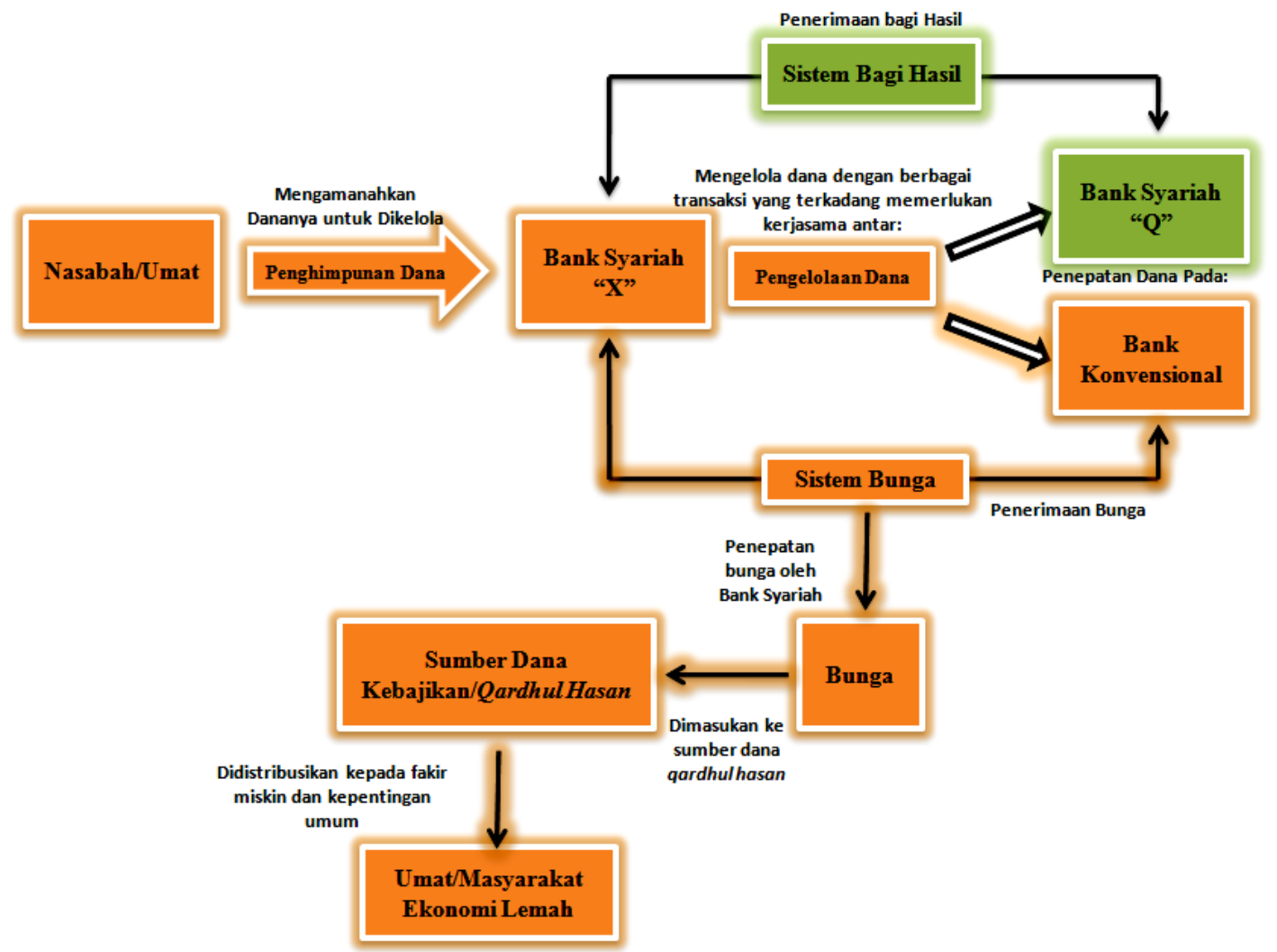

Sumber: Hasil Wawancara dengan Ustaz H. Abdul Shomad, LC., D.E.S.A (Informan)

Tujuan mengembalikan dana umat kepada umat dijelaskan oleh informan bahwa bukan tergolong sebagai sedekah melainkan untuk mensucikan perbankan syariah dari pendapatan haram ini. Karena Allah tidak menganggap sebuah pahala atas sumber sedekah kecuali yang thoyib (suci). Hal ini didasarkan pada sebuah pernyataan 
informan yang menjelaskan bahwa "Allah Maha Suci, Allah menerima kecuali yang suci."

\section{Penggunaan secara konsumtif bukan produktif (Pinjaman bergulir)}

Dalam ED PSAK 101 (revisi):

Penyajian Laporan Keuangan Syariah secara khusus mengenai laporan sumber dan penggunaan danakebajikan menjelaskan bahwa penggunaan dana qardhul hasan pada perbankan syariah digunakan untuk pinjaman, sedekah, dan lainnya. Penggunaan dana qardhul hasan disalurkan untuk kepentingan umum,dan sedekah sebagai pemberdayaan masyarakat ekonomi lemah bisa disebut bersifat konsumtif. Dalam hal ini, bersifat konsumtif maksudnyapenyaluran dana untuk pemberdayaan masyarakat ekonomi lemah dalam memenuhi kebutuhan hidupnya yang habis pakai. Berbeda dengan penggunaan secara produktif dalam bentuk pinjaman atau qardh. Ada pun, Ustaz $\mathrm{H}$. Abdul Shomad, LC., D.E.S.A dalam hal ini cenderung dana qardhul hasan dimanfaatkan untuk kepentingan umum, dan untuk secara konsumtif alih-alih produktif.Karena berdasarkan pendapatan dari fatwa-fatwa ataupun mufti ulamaulama menyatakan secara jelas pemanfaatan bunga bank boleh digunakan bahkan ada yang mengatakanwajib dialokasikan untuk kepentingan umum dan asyarakat ekonomi lemah.

"Saya lebih setuju, kalo dalam semester ini dapat dana non halal dapat misalnya seratus juta, jangan diputar lagi. Saya lebih condong pendapat mayoritas. Murni konsumtif. Untuk biaya anak sekolah, untuk pembangunan MDA, jangan diputar dengan pinjaman lalu dikembalikan. ....Saya lebih setuju yang untuk dana konsumtif, habis."

Pencampuran

penerimaan pendapatan halal dan pendapatan non halal (haram) pada sumber dana qardhul hasan menjadi dilematik. Hukum haram yang melekat pada bunga diakui sebagai kewajiban yang wajib dikeluarkan oleh entitas untuk kepentingan sosial. Dalam penelitan Solehudin, Auliyah dan Zuhdi (2014) mengungkapkan bahwa pendapatan non halal sudah selayaknya mencatat dan melaporkan pendapatan non halal secara terpisah dari laporan sumber dan penggunaan dan kebajikan. Sebab kehatihatian dan ketelitian dalam pengelolaan pendapatan non halal haruslah terjaga oleh perbakan syariah. Bukan hanya karena menjaga dan menghindari salah catat atau kekeliruan yang materialistas dalam sebuah laporan keuangan, namun sebagai tanggung jawab terhadap sebuah pengelolaan yang bijak dan bajik mengingat bahwa bunga adalah sumber bencana ekonomi.

Ada pun jika dibuat sebuah skema pengalokasian dana kebajikan secara konsumtif untuk pemberdayaan fakir miskin dan penggunaan untuk kepentingan umum, serta dalam bentuk pinjaman lunak (qardhul hasan) akan terlihat seperti pada gambar 3 berikut ini : 


\section{Gambar 3 Alokasi Sumber Dana Qardhul Hasan (Dana Kebajikan)}

\section{Sumber Dana Qardhul Hasan}

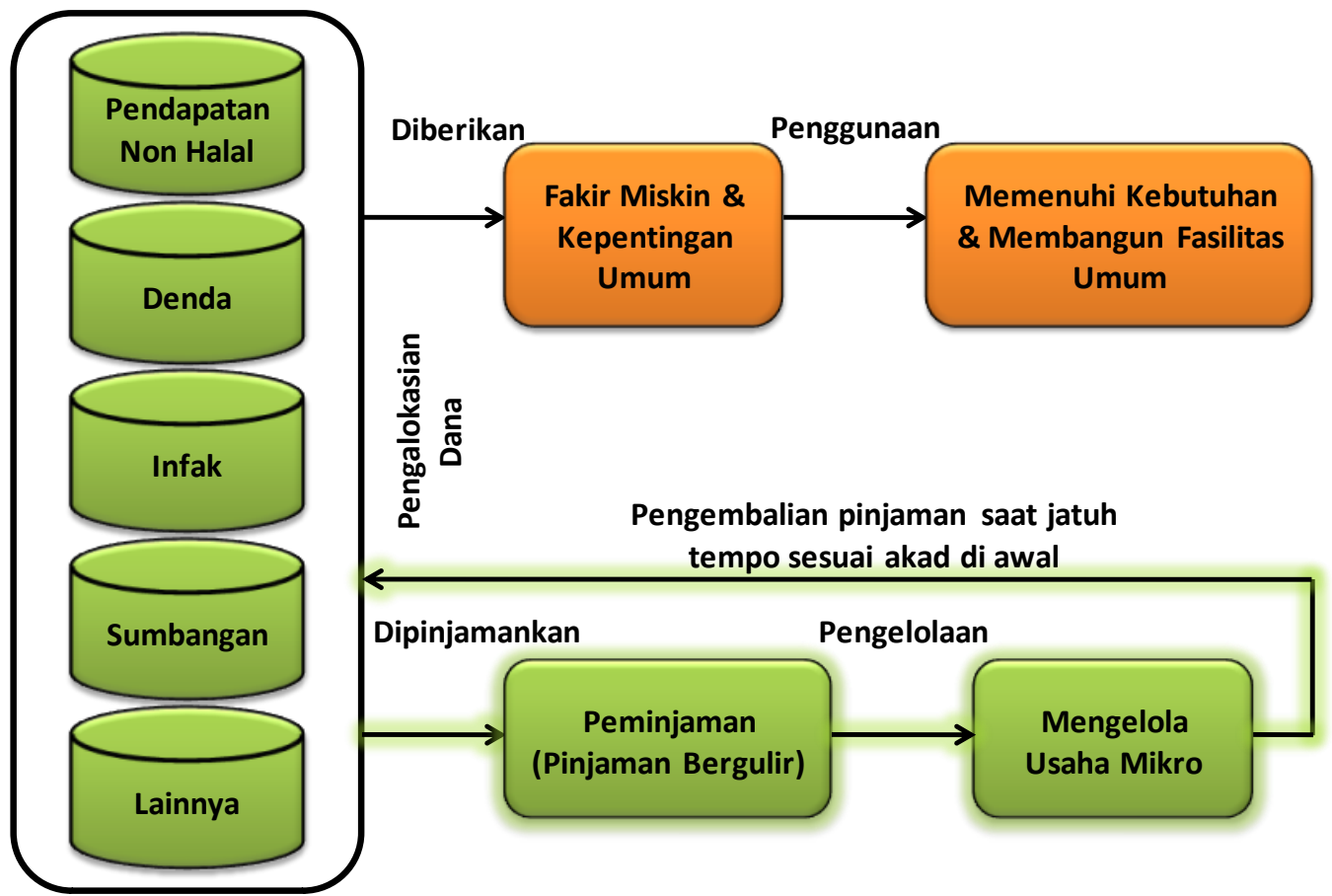

Sumber: Analisis hasil wawancara peneliti dengan Ustaz Abdul Shomad (Informan)

Dapat dilihat pada gambar 3 bahwa penyaluran dana secara konsumtif penggunaan untuk kepentingan umum diberikan secara sukarela. Sehingga, dalam hal ini sesuai dengan mengembalikan dana umat kepada umat. Kondisi yang berbeda jika dana qardhul hasan disalurkan dalam bentuk pinjaman produktif. Adanya kewajiban penerimaan dana untuk mengembalikan dana tersebut pada saat jatuh tempo. Sehingga tujuan perbankan syariah untuk membersihkan diri dari penerimaan non halal belum sesuai dengan yang diharapkan. Sebab pendapatan non halal belum seutuhnya bersih dari perbankan syariah.
Pemanfaatan pendapatan non halal: tidak ahsan digunakan sebagai sumber dana qardhul hasan

Haram Diambil Haram Pula Diberikan

Dalam sebuah kaidah menyebutkan bahwa "Apa saja yang diharamkan untuk mengambilnya maka diharamkan pula memakannya dan diberikan kepaada orang lain." Kaidah ini dikutip oleh Prof. Dr. Akhmad Mujahidin, M. Ag. sebagai dasar argumen informan yang menyatakan bahwa bukanlah tindakan yang bijak menggunakan pendapatan non halal tersebut pada salah satu sumber qardhul hasan.

"Uda salah kalau ini, seharusnya harus spin off. Ga boleh ada pendapatan non halal lagi. Ini continuity. Haram 
jadinya. ....Maka di sini ada sebuah kaidah. "Apa saja yang diharamkan untuk mengambilnya maka diharamkan pula memakannya dan memberikannya kepada orang lain."

Ada pun, maksud kaidah ini adalah dua kegiatan yang kausalitas (sebab-akibat) yang terikat satu sama lain, maka hukumnya dipararelkan. Jika suatu akibat dari aktifitas kegiatan yang dinilai haram, maka aktifitas sebelumnya yang merupakan sebab munculnya keharaman, maka diharamkan pula. Ini sebagai konsekuensi logis untuk mewujudkan kemaslahatan yang lebih komprehensif dari sebuah pelarangan (Ramadhansyah, 2013).

Pernyataan informan tersebut menegaskan bahwa haram hukumnya pendapatan non halal dimanfaatkan untuk memperdayakan masyarakat ekonomi lemah, sebagaimana diharamkan mengakui bunga sebagai pendapatan operasional perbankan syariah. Sebab bukan suatu alasan pembenaran atas pemanfaatan riba untuk upaya pemberdayaan masyarakat ekonomi lemah.

Sebagaimana hukum haram yang melekat pada bunga, upaya penghentian penerimaan dana non halal harusnya menjadi suatu prioritas. Seperti dalam pernyataan informan bahwa spin off atas penerimaan bunga harus dilakukan sebagai bentuk harga diri bank syariah untuk menjaga prinsip syariah yang bebas riba.

"Ya pendapatan non halal kok diterima, ya ga boleh. Kalau mau yang sebenarnya. Ga ada mudharat untuk kita jika kita tidak menerima. Tidak ada. Ini kita bisa dijengkali sama konvensional. 'Ente.... mau juga bunga kami'. Disitu kita ga bisa begak jadinya. Qardhul hasan itu dari zakat, infak, sedekah. Kenapa harus dicampur dengan non halal."

Selanjutnya, Prof. Dr. Akhmad Mujahidin, M.Ag menguatkan argumen dengan pernyataan di atas. Pencampuran dana halal dan non halal dalam sumber dana qardhul hasan yang dilakukan perbankan syariah seharusnya dihindari. Jika perbankan syariah memprioritaskan menjalankan prinsipnya secara komprehensif (kaffah) walaupun dengan bertahap.

Hal yang senada disampaikan oleh Dr. Aji Dedi Mulawarman, informan menolak secara mutlak pemanfaatan bunga dalam dana qardhul hasan digunakan untuk masyarakat ekonomi lemah. Untuk itu perbankan syariah harus menghindari penerimaan bunga dalam operasionalnya. Sebab secara eksplisit, informan menyatakan bahwa untuk menghindari riba dalam perbankan syariah maka yang dilakukan adalah tidak mengambil sesuatu ukuran berbasis interest (kepentingan), dalam hal ini bunga adalah kepentingan. Sehinggga menghindari transaksi yang menimbulkan bunga pada bank syariah merupakan wujud dari pelaksanaan prinsip syariah secara komprehensif (kaffah).

"Kalau segala sesuatu diambil ukurannya berbasis pada kepentingan/interest. Wong riba itu kan interest. Interest itu kan kepentingan. Jadi kalo bank itu cara berpikirnya riba, ya sudah pasrah. Itu kalo melihat pendapatan non halal, yah lumayan itu pakai aja. Kan itu kepentingan. Kalau pun katanya untuk dana kebajikan. Namun, namanya sudah barang rongsok, ini kan namanya menjebak orang dalam keburukan." 
Penggunaan pendapatan non halal untuk kepentingan umum

Penggunaan pendapatan non halal dalam dana qardhul hasan sebagai wujud sosial tidak bisa dikatakan keputusan bijak, dan bajik. Sebab pada sisi Allah SWT penggunaan ini tidak dianggap sebagai sedekah karena Allah Maha Suci menerima kecuali yang suci.

"Kalau untuk kepentigan umum seperti jalan raya, jembatan boleh deh. Dari pada mubazir. Tapi kalo untuk konsumsi, jangan. Daging yang tumbuh dari barang haram neraka tempatnya. Konteks qardhul hasan untuk orang miskin kan. ....Tapi kalo untuk kosumsi, investasi seperti beasiswa, itu kan investasi. Jangan! Haram itu. .... Begitu pun, untuk modal usaha. Usaha itu kan hasilnya untuk dimakan (konsumsi). Jangan!. Harus hati-hati."

Pernyataan Prof. Dr. Akhmad Mujahidin, M.Ag. menanggapi positifatas penggunaan dana non halal untuk kepentingan umum yang sifatnya non konsumsi. Dalam pernyataannya, kepentingan umum yang dimaksud seperti membangun jembatan, rekontruksi jalan raya dan lainnya yang sejenis. Ide ini didasarkan pada premis (asumsi) bahwa hal ini dilakukan sebagai bentuk kehatihatian jika penggunaannya untuk dikonsumsi. Informan memperkuat premisnya (asumsi) dari sebuah hadis, yaitu "daging yang tumbuh dari barang haram neraka tempatnya."Ada pun, informan juga menjelaskan jika penggunaan pendapatan non halal ini untuk pinjaman modal usaha, hukumnya sama, yaitu haram. Sebab dalam jangka pendek atau pun panjang akan menerima hasilnya yang hasilnya jelas untuk dikonsumsi.
Konsisten dengan pandangan informan sebelumnya, Bapak Imdibkri selaku praktisi di salah satu perbankan syariah mengungkapkan hal yang demikian. Penggunaan pendapatan non halal selayaknya di alokasikan dalam bentuk yang bersifat non konsumsi namun disalurkan pada fasilitas umum seperti membangun jalan, jembatan dan sejenisnya.

Menurut data yang diperoleh dari otoritas jasa keuangan menyatakan sumber dan penggunaan dana kebajikan pada perbankan syariah periode Desember 2013. Pada tabel 4.2 menjelaskan sumber dan penggunaan dan kebajikan berdasarkan Laporan Sumber dan Penggunaan Dana Kebajikan pada perbankan syariah periode 2014. Tahun 2014 Bank Mualamat mengungkapkan sumber dana kebajikannya yang berasal dari denda yaitu sebesar 2.337.000.000,00 dan pendapatan non halal sebesar 1.637.000.000,00. Sedangkan penggunaan dana tersebut tidak diungkapkan oleh Bank Muamalat. Pada Bank Syariah Mandiri sumber dana kebajikan hampir sama dengan periode sebelumnya dimana berasal dari denda, pendapatan non halal dan lainnya, dan penggunaanya digunakan untuk kategori lainnya yaitu sebesar Rp 2.252.000.000,00. Begitu pula Bank BNI Syariah mendapatkan sumber dan penggunaan yang sama pada periode sebelumnya. Namun, terjadi penurunan penerimaan sumber dana walaupun tidak begitu signifikan. Sedangkan penggunaan dana tersebut mengalami peningkatan \pm 5 kali lipat dari penggunaan dana sebelumnya yaitu sebesar Rp 899.000.000,00. Peningkatan penerimaan dana kebajikan dari periode sebelumnya dialam juga oleh Bank Bukopin Syariah sebesar 57,7\%, Bank Jabar Banten 
meningkat 72,9\%, Bank Mega Syariah meningkat 135,1\%, dan Bank Maybank Syariah Indonesia meningkat 183,1\%. Meski begitu peningkatan dana kebajikan tidak sebanding dengan peningkatan penggunaan dana tersebut, justru terjadi penurunan dalam pengalokasi dana kebajikan.

Selanjutnya Bank BRI Syariah mengungkapkan sumber dana kebajjikannya berasal dari denda, sumbangan/hibah, dan pendapatan non halal, dalam hal ini terjadi decrease dalam sumber dananya walaupun tidak signifikan, turun sekitar 18,5\%. Sedangkan Bank BCA Syariah penerimaan dananya bergerak statis (tetap) pada Rp 418.000.000,00 dari tahun sebelumnya untuk penggunaannya digunakan untuk kategori lainnya sebesar Rp 211.000.000,00.

\section{Expectation (harapan) pada transparansi pendapatan non halal}

Ada pun pendapatan non halal harusnya mengungkapkan informasi bagaimana transaksi tersebut bisa terjadi dan bagaimana cara mengantisipasinya. Sehingga stakeholdersmenerima informasi secara transparan. Berdasarkan penjelasan dari Haniffa \& Hudaib (2004) dalam Iqbal (2012) salah satu dasar untuk entitas syariah untuk menunjukkan komitmen yang tulus terhadap tanggung jawab sosial adalah dengan pengungkapan.

Dalam hal ini, perlu kesadaran akan pentingnya pengungkapan untuk semua transaksi yang berhubungan dengan dana qardhul hasan. Konsisten dengan hasil penelitian Iqbal (2012) bahwa dana kebajikan bertujuan sosial, suatu perbuatan yang dilakukan untuk tujuan baik akan menerima berkat Ilahi (berkah). Berkat ini kemungkinan nasabah telah memberikan kepercayaan mereka kepada pengelola dana (perbankan syariah), dan ketika mereka percaya, nasabah akan termotivasi untuk mengulangi tindakan amal mereka. Hasil Schoorman et al. (2007) dalam Iqbal (2014) telah menunjukkan bahwa tindakan amal akan mengakibatkan munculnya efek kepercayaan yang memotivasi individu untuk mengulangi tindakan yang sama.

Pencampuran dana halal dan non halal dalam sumber dana qardhul hasan bukanlah keputusan yang bijak dan bajik karena hukum haram yang melekat pada bunga. Maka harus digunakan secara hatihati. Pada penelitian Solehudin, Auliya dan Zuhdi (2014) mencoba memberikan suatu solution atas pendapatan non halal, yaitu pemisahan pendapatan non halal dari laporan sumber dan penggullaan dana kebajikan. Dalam penelitian tersebut juga membuat contoh laporan pendapatan non halal yang terpisah dari laporan dana kebajikan. Bahkan bukan hanya pemisahan laporan namun dana pendapatan non halal dibatasi penggunaanya untuk suatu hal yang memerlukan pendapatan non halal. Sehingga pendapatan non halal harus masuk-keluar dari pintu pendapatan non halal.Dalam hal ini, jalan keluarnya adalah pendapatan non halal digunakan untuk sumbangan atau hibah kepada Negara Indonesia untuk dibayarkan kepada bunga akibat pinjaman negara upaya penutup anggaran untuk kebutuhan bangsa.Maka bunga diserahkan kepada bunga.

Namun Ustaz H. Abdul Shomad, LC., D.E.S.A menanggapi berbeda jika pendapatan non halal ini dialokasikan kepada Negara. Sebab suatu negara sudah memiliki APBN, yang secara khusus menanggulangi kemiskinan. Sehingga lebih efektif dan efesien dana non halal dialokasikan secara langsung oleh 
perbakan syariah atau pun diserahkan kepada lembaga sosial yang dapat mengelola dana tersebut untuk kepentingan umum.

"Saya dalam hal ini mengikut pendapat ulama yang lehih banyak.Karena lebih selamat. Jadi dana itu tidak ke Negara. Negara sudah punya ABPN, APBD.Mestinya, dalam undang-undang kita, orang miskin itu ditanggung Negara. Sekarang malah dana itu di diberikan ke Negara. Apalagi Negara yang tidak amanah. Akan sulit teridentifikasi dana itu. Maka bagusnya, yang mendapatkan dana non halal tadi, langsung aja diserahkan."

Bagaimana pun keharusan pengungkapan pendapatan non halal pada perbankan syariah sesuatu urgent.Pengungkapan laporan dana kebajikan secara tranparan atas alasan terjadinya dan penggunaan pendapatan non-halal pada catatan atas laporan keuangan harus menjadi prioritas upaya menjalankan prinsip syariah secara kaffah.

Upaya kehati-hatian dalam mengelola pendapatan non halal pada perbankan syariah secara komprehensif(kaffah). Menurut Prof. Dr. Akhmad Mujahidin, M. Ag adalah dengan spin off, menghentikan penerimaan bunga dalam perbankan syariah.Karena untuk mencapai prinsip syariat Islam dalam operasional harus terhindar dari penerimaan haram (bunga). Konsisten dengan yang disampai oleh Dr. Aji Dedi Mulawarman bahwa yang membedakan perbankan syariah dengan perbankan non syariah adalah dari paradigmanya, jika paradigmanya mengambil suatu ukuran berbasis pada kepentingan (bunga) maka untuk menghindari bunga dalam perbankan syariah menjadi sulit terealisasi. Sehingga keputusan yang paling bijak dan bajik adalah memutuskan segala transaksi yang menimbulkan bunga yang tujuannya meilialan prinsip syariat Islam secara kaffah.

Namun disamping ekspektasi tersebut, kondisi realitas menunjukan hal yang berbeda.Penerimaan pendapatan non halal pada perbankan syariah timbul secara kontinu.Seharusnya tidak ada toleransi untuk mengakui pendapatan sejak status pendapatan tersebut adalah haram, meskipun dalam kasus tertentu, diakui itu bisa terjadi.Seharusnya diupayakan adanya penjelasan tentang bagaimanatransaksi (bunga) tersebut bisa terjadi dan bagaimana cara mengantisipasinya.

Dengan pengungkapan secara transaparan mengenai danaqardhul hasan khususnya dana non halal akan berorentasi pada kepercayaan publik.Dalam hal ini, menurut analisis peneliti upaya pengungkapan yang perlu dilakukan yaitu dengan memisahkan penggunaan pendapatan non halal pada pengalokasian dana yang bersifat konsumtif dan khususnya pinjaman produktif. Walaupun pendapatan non halal terakumulasi dengan sumber lainnya pada danaqardhul hasan. Namun,hal ini diantisipasi dengan mengungkapkannya pada laporan keuangan atau pun catatan atas laporan keuangan.Sehingga pendapatan non halal khusus hanya dialokasikan untuk kepentingan umum, seperti kontruksi jalan raya, pembangunan jembatan dan lainnya.

Hal ini, dilakukan untuk menghindari pencampuran dana halal dan non halal dalam penggunaannya. Sebab alokasi dengan pinjaman dalam penggunaan dana kebajikan, harus dihindari dari sumber 
dana non halal. Karena mengingat penggunaan pendapatan non halal secara produktif (pinjaman) bukanlah keputusan yang bijak dan bajik untuk dilakukan. Maka pemisahaan penggunaan dana halal dan non halal pada sumber dana qardhul hasan perlu dilakukan. Dalam hal ini, sumber qardhul hasan dari pendapatan non halal digunakan khusus untuk kepentingan umum. Sedangkan, sumber dana halal bisa digunakan untuk pinjaman produktif, sumbangan dan lainnya yang bersifat konsumtif.

\section{SIMPULAN}

Analisis pandangan informan mengenai fenomena pemanfataan pendapatan non halal pada danaqardhul hasan memiliki pespektif yang berbedabeda. Hasilnya menunjukan terdapatdua pandangan yang berbeda terkait fenomena, yaitu pandanganpertama, ahsan digunakan sebagai sumber danaqardhul hasan. Dalam hal ini,penggunaan-nya alokasikan pada kepentingan umum atau fakir miskin. Pandangan kedua, yaitu menolak penggunaan pendapatan non halal pada sumber danaqardhul hasan. Hal ini didasarkan, pada asumsi bahwa jika suatu akibat aktifitas kegiatan yang dinilai haram, maka aktifitas sebelumnya yang merupakan munculnya keharaman.Sehingga sesuatu yang bersumber dari yang haram tidak layak difungsikan bahkan diberikan.Namun demikian, pengecualian jika pendapatan non halal dimanfaatkan untuk kepentingan umum, hal ini tergolong dibolehkan dari pada dari pada mubazir.

Hasil analisis menunjukkan walaupun perbedaan pandang dari pernyataan informan terdapat hubungan atau keterkaitan pemahaman, dalam hal ini yaitu sebagai berikut:

1. Pendapatan non halal boleh digunakan pada danaqardhul hasan. Hal ini didasarkan pada asumsi bahwa mengembalikan dana umat kepada umat yang bertujuan untuk membersihkan diri dari benda haram. Namun pemisahan penggunaan perlu diprioritaskan dengan memisahkan penggunaan pendapatan non hal yang khusus dialokasikan untuk kepentingan umum (fasilitas umum) seperti kontruksi jalan, membangun jembatan dan lainnya. Sedangkan sumber qardhul hasan yang bersumber dari dana halal dialokasikan untuk sumbangan yang bersifat konsumtif atau pinjaman bergulir (qardhul hasan).

2. Upaya kehati-hatian dalam mengelola pendapatan non halal pada perbankan syariah secara kaffah (komprehensif) menurut Prof. Dr. Akhmad Mujahidin, M. Ag adalah dengan spin off, menghentikan penerimaan bunga dalam perbankan syariah. Karena untuk mencapai prinsip, syariat Islam dalam operasional harus terhindar dari penerimaan haram (bunga). Konsisten dengan yang disampaikan oleh Dr. Aji Dedi Mulawarman bahwa yang membedakan perbankan syariah dengan perbankan non syariah adalah dari paradigmanya, jika paradigmanya mengambil suatu ukuran berbasis pada kepentingan (bunga) maka untuk menghindari bunga dalam perbankan syariah hanya menjadi suatu expectation tanpa ada realisasi. Sehingga keputusan yang paling bijak dan bajik adalah memutuskan segala transaksi yang menimbulkan bunga, yang tujuannya menjalan prinsip 
syariat Islam secara komprehensif(kaffah).

3. Pengungkapan secara transaparan menjadi orientasi peningkatan kepercayaan publik. Menurut analisis peneliti upaya pengungkapanperlu dilakukan yaitu memisahkan penggunaan pendapatan non halal pada pengalokasian dana yang bersifat konsumtif dan khususnya pinjaman produktif (qardul hasan). Walaupun pendapatan non halal terakumulasi dengan sumber lainnya pada danaqardhul hasan. Namun, hal ini dapat diantisipasi dengan mengungkapkannya pada laporan sumber dan penggunaan dana kebajikan atau pun catatan atas laporan keuangan. Sehingga pendapatan non halal khusus hanya dialokasikan untuk kepentingan umum, seperti kontruksi jalan raya, pembangunan jembatan dan lainnya.

\section{DAFTAR RUJUKAN}

Antonio, Muhammad Syafi'i. (2013). Bank Syariah: Dari Teori Ke Praktik. Jakarta: Gema Insani

Badaruddin. (2011). Manajemen Pembiayaan Produk Qardhul Hasan: Studi Kasus Di BPRS Metro Lampung Tahun 2011. Tesis. Yogyakarta: Program Pasca

Sarjana UIN Sunan Kali Jaga

Burhanudin. (2012). Pemahaman Dan Penerapan Al-Qard Al-Hasan Pada KJKS BMT Haniva. Skripsi. Yogyakarta: UIN Sunan Kali Jaga

Bank Indonesia. (2003). Pedoman Akuntansi Perbankan Syariah Indonesia (PAPSI)
Budiman, Farid. (2013). Karakteristik Akad Pembiyaan Al-Qardh Sebagai Akad Tabarru'

Chair. Wasilul. Riba Dalam Perspektif Islam

Dewan Standar Akuntansi Keuangan. (2014). Exposure Draft Pernyataan Standar Akuntansi Keuangan No. 101. Jakarta: Ikatan Akuntansi Indonesia

Dewan Syariah Nasional-MUI. (2001). Datwa Dewan Syariah Nasional No: 19/DSN-MUI/IV/2001

Gunawan, Imam. (2013). Metode Penelitian Kualitatif: Teori \& Praktiki. Jakarta: Bumi Aksara

Hermawan, Hendri. (2008). Sumber dan Penggunaan Dana Qardh Dan Qardhul Hasan Pada Bank Syariah Cabang Yogyakarta. Skripsi. Yogyakarta: Fakultas Agama Islam Universitas Islam Indonesia

Iqbal, M. (2012). The Meaning Of Disclosure of Sources And Uses of Benevolent Fund (Qardhul Hasan) Of Syariah Banks: A Study Based On Symbolic Interaction And God Trilogy Teaching

Martono, Nanang. (2015). Metode Penelitian Sosial: Konsep-Konsep Kunci. Jakarta: Rajawali Press

Maulidha, Erina dan Air Nur Bayinah. (2014). Kerangka Pengungkapan Transaksi Non-Halal Di Bank Syariah. SNAS 2014

Muqarrabin, Ahmad. (2012). Warung Ekonomi Islam. http://warungekonomiislam.blogspot .com. Diakses 23 Oktober 2015

Nuradilla, Masschuraini. Oman Rusmana dan Warsidi. Studi Fenomenologi Peran Laporan Keuangan Dalam Mmfasilitasi Kredit Usaha Rakyat (KUR). Mataram: SNA 17 
Nurhayati, Sri dan Wasilah. (2015). Akuntansi Syariah Di Indonesia. Jakarta: Salemba Empat

Otoritas Jasa Keuangan. (2015). Roadmap Perbankan Syariah Indonesia 20152019

Otoritas Jasa Keuangan. Laporan Publikasi Sementara. www.ojk.go.id. Diakses pada 19 Desember 2015

Purwadi, Muhammad Imam. (2011). Qardhul-Ahsan Dalam Perbankan Syariah: Konsep Dan Implementasinya Berdasarkan Prinsip Manfaat Bagi Pemberdayaan Masyarakat. UNISIA. Vo. XXXIII No.74

Purwadi, Muhammad Imam. (2014). AlQardh dan Al-Qardh Hasan Sebagai Wujud Pelaksanaan Tanggung Jawab Sosial Perbankan Syariah. Jurnal Hukum IUS QUIA IUSTUM. Vol. 21 No. 1

Sjahdeini. Sutan Remy. (2014). Perbankan Syariah: Produk-Produk Dan AspekAspek Hukumnya. Jakarta: Kencana Prenademia Group

Solehodin, Robiatul Uliyah dan Rahmat Zuhdi. (2014). Ahsankah Pendapatan Non Halal Pada Qardhul Hasan?. SNA 2014

Sugiono. (2013). Metode Penelitian Kuantitatif, Kualitatif Dan Kombinasi (Mixed Methods). Alfabeta: Bandung

Utomo, Anif Punto. et. Al. (2014). Dua Dekade Ekonomi Syariah: Menuju Kiblat Ekonomi Islam. Jakarta: Gress

Rahmadina, Hana. (2015). Penerapan PSAK No 101 Pada Penyusunan Laporan Keuangan PT Bank Madiri Syariah

Ramdhansyah, Ferry. (2013). Kaidah ke-27 Sesuatu Yang Haram Diambil. Maka Haram Pula Diberikan. htttp://pustakasharia.blogspot. co.id/2013/04/kaidah-ke-7-sesuatuyang-haram-diambil. Diakses pada 09 maret 2016

Wiroso. 201 Produk Perbankan Syariah. Jarkarta: LPEE Usaksi

www.syariahmandiri.co.id. Diakses pada 30 Januari 2015

www.bnisyariah.co.id. Diakses pada 30 Januari 2015 